\title{
Status and conservation of primates in Odzala National Park, Republic of the Congo
}

\author{
Magdalena Bermejo
}

\begin{abstract}
A survey of diurnal primate populations was carried out in Odzala National Park, Republic of the Congo, over 3 months in 1994 and 2 months in 1995. The park contains a high diversity and species-specific abundance of primates, and has the highest number of diurnal primates (10 species) in the forest block of Central Africa. Eight species of monkey: greater whitenosed monkey Cercopithecus nictitans, moustached monkey Cercopithecus cephus, crowned guenon Cercopithecus pogonias, De Brazza's monkey Cercopithecus neglectus, talapoin Miopithecus talapoin, white-cheeked mangabey Cercocebus albigena, agile mangabey Cercocebus galeritus and guereza Colobus guereza, as well as gorilla Gorilla g. gorilla and chimpanzee Pan t. troglodytes were sighted in the survey. Monkey species richness was highest in dense inundated forest and thicket, with all eight species occurring in these habitats, whereas only four species were found in terra firma forest (consisting of the park's two main habitats, open-canopy Marantaceae forest and closed-canopy primary forest). Three of
\end{abstract}

the four species (C. nictitans, C. cephus and C. albigena) present in terra firma forest were most abundant in closed-canopy primary forest $(1.4,1.0$ and 0.6 groups per $\mathrm{km}$, respectively) while the fourth (C. pogonias) was most abundant in open-canopy Marantaceae forest. Gorilla nests were most abundant in open-canopy Marantaceae forest (12.1 nests per $\mathrm{km}$ ), while chimpanzee nests were mostly found in closed-canopy primary forest and Marantaceae forest (14 and 12 nests per $\mathrm{km}$, respectively). Odzala has the highest recorded densities of western lowland gorilla (mean $=5.4$ individuals per sq $\mathrm{km}$ ) and chimpanzee (mean $=2.2$ individuals per sq $\mathrm{km}$ ) in Central Africa. The high densities of gorillas and chimpanzees may be a result of the high productivity of the forest and low poaching pressure. Conservation measures to ensure the maintenance of conditions in the area, such as educational programmes, are suggested.

Keywords Congo, conservation, density, primate diversity, surveys.

\section{Introduction}

Primate populations in the Republic of the Congo (Congo) have received little attention, although some information on their distribution and population densities has been recorded (Regusters, 1983; Fay et al., 1990; Kuroda, 1990; Mitani, 1990, 1992; Nishihara, 1990; Oko, 1990; Fay \& Agnagna, 1992; Blake, 1995). Since 1992 the regional programme 'Conservation and Rational Utilization of Tropical Forest Ecosystems in Central Africa' (ECOFAC), which is funded by the European Union and implemented by AGRECO-CIRAD Forêt, has undertaken a variety of surveys in the subregion to collect information on biodiversity, and ensure its conservation through the sound management of protected areas and the development of sustainable activities for the local people. To this end, surveys of primate populations have

\footnotetext{
Magdalena Bermejo Zoology Department, Faculty of Biology, University of Barcelona, Av. Paral-lel 159, 2-3, 08004 Barcelona, Spain. Tel.: + 349342375 80; e-mail: magdabermejo@jet.es; and ECOFAC, Cellule de Coordination, BP 15115, Libreville, Gabon. E-mail: ecofac.coord@internetgabon.com or coordination@ecofac.org
}

been conducted in several protected areas in Central Africa (Garcia \& Mba, 1997; this study). Since 1992 ECOFAC has been responsible for overseeing the management of Odzala National Park (ONP), and in 1994 a survey of the diurnal primate populations in the park was conducted over a 5-month period in order to assess their relative abundance and conservation status.

\section{Study area}

The Republic of the Congo is a large country $(342,000 \mathrm{sq} \mathrm{km})$ with forests covering nearly two-thirds $(222,300 \mathrm{sq} \mathrm{km})$ of the area. Human population density is low (c. 6 people $/ \mathrm{sq} \mathrm{km}$ ) with approximately 50 per cent of the population in towns and cities, leaving the countryside relatively unpopulated. The contiguous ONP, Lékoli-Pandaka Faunal Reserve and M'boko Hunting Reserve cover nearly $5000 \mathrm{sq} \mathrm{km} \mathrm{(Heck-}$ etsweiler et al., 1991). The $2848 \mathrm{sq} \mathrm{km}$ of ONP is north of the equator $\left(0^{\circ} 23^{\prime}-1^{\circ} 10^{\prime} \mathrm{N} ; 14^{\circ} 39^{\prime}-15^{\circ} 11^{\prime} \mathrm{E}\right)$ on the north-western fringe of the Congo River watershed, at an altitude of between 300 and $600 \mathrm{~m}$ (Fig. 1). The western and northern areas of Odzala are hilly with steep slopes and a dense network of watercourses. There 
are two wet seasons, from October to December and from March to May. The average annual rainfall is $1509 \mathrm{~mm}$ (M'boko data, 1994). Temperatures vary little over the year but are lowest during the dry season when there is constant cloud cover during the daytime.

Odzala National Park is characterized by a rich diversity of habitats (primary forest, both on terra firma and inundated soils, Marantaceae forest (evergreen forest with a dense understorey of Marantaceae species), clearings and savannahs (Hecketsweiler et al., 1991; Lejoly, 1996). Two major habitat types, terra firma forest and riparian forest, were surveyed and these were divided into five subtypes depending on canopy structure, plant species and moisture content of the soil (Dowsett-Lemaire, 1995; Maisels, 1995; Lejoly, 1996).

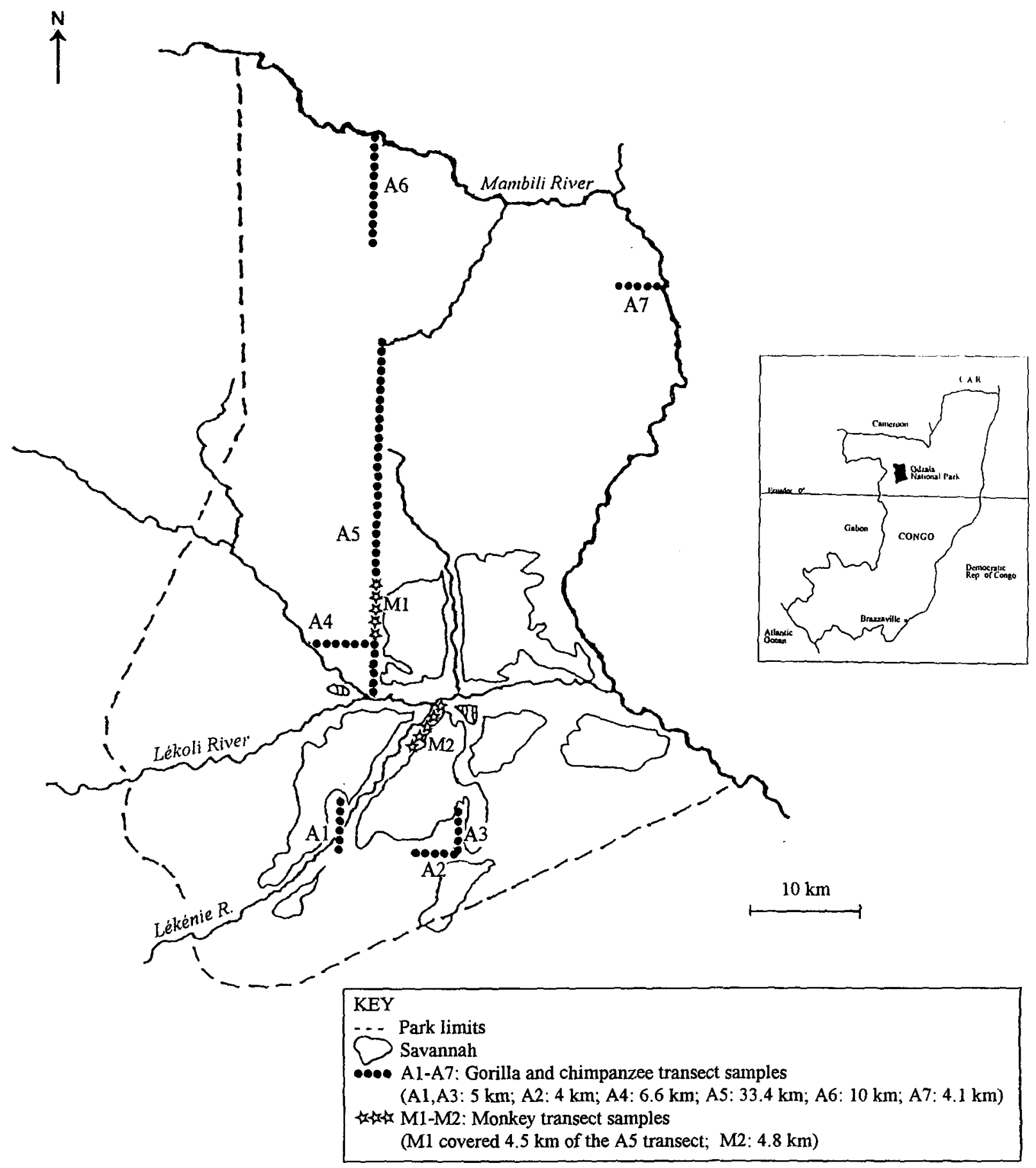

Fig. 1 Location of transects for the primate survey, Odzala National Park, north Congo. 
Terra firma forest consisted of areas of open-canopy Marantaceae forest (the dominant vegetation to the north of the Lékoli River, particularly in the north-eastern part of the park) and closed-canopy primary forest (abundant in the western part of the park). Riparian forest (well represented along the Lékoli and Mambili rivers) consisted of areas of thicket, swamp and dense inundated forest occurring on perpetually waterlogged and often seasonally inundated soils. Two other habitat types were not surveyed: clearings, which are swampy areas distributed patchily and mostly situated near rivers with sedges (Cyperaceae) such as Rhynchospora sp. as the dominant species (Vanleeuwe et al., 1998); and savannah areas (the dominant vegetation type to the south of the Lékoli River), dominated by Graminae (Andropogon schirensis) with scattered fire-resistant shrubs (Hymenocardia acida and Annona senegalensis).

The major distinguishing features and dominant species of each vegetation type after Dowsett-Lemaire (1995), Maisels (1995) and Lejoly (1996) are listed below. 1 Open Marantaceae forest, in which the canopy is discontinuous, allowing light to penetrate to the forest floor. The middle-storey canopy cover is particularly sparse. Characteristic species are Erythrophleum suaveolens, Pentaclethra macrophylla, Milletia laurentii, Santiria trimera, Diospyros sp. nov., Vernonia brazzavillensis, Markhamia tomentosa, Croton mayombense, Sapium cornutum, Pausinystalia spp. and Caloncoba welwitschii. An almost impenetrable thicket of Marantaceae speciesHaumania liebrechtsiana, Megaphrynium macrostachyum and Sarcophrynium sp.-dominates the ground vegetation.

2 Closed-canopy forest, in which the canopy cover is more continuous than in open Marantaceae forest, especially in the middle storey $(10-20 \mathrm{~m})$. The understorey is sparse. Erythrophleum suaveolens, Lophira alata, Pentaclethra macrophylla, Milletia laurentii, Isolona hexaloba, Chaetocarpus africanus, Santiria trimera, Strombosia pustula, Pausinystalia macrophylla and Camptostylus mannii are the most common species.

3 Thicket forest along streams or rivers is dominated by Dichostemma glaucescens, Homalium africanum and Baphia laurifolia, with often a high incidence of rattan palms (Calamus spp. and Ancistrophyllum spp.).

4 Swamp forest is characterized by permanently flooded or waterlogged soils, with Xylopia spp., Raphia sp. and Klaineanthus gaboniae as the most common species.

5 Dense inundated forest is a low closed-canopy formation with very little understorey and with a Gilbertiodendron ogoouense/Cryptosepalum congolaneum/Baphia laurifolia association.

Open-canopy Marantaceae forest, which often has a canopy density of less than 10 per cent and resembles savannah when observed from the air (Fay, 1997), is the dominant vegetation over an area of about $20,000 \mathrm{sq} \mathrm{km}$, including the area of ONP (Rollet, 1964; Letouzey, 1968).

\section{Methods}

\section{Monkey census}

The monkey census was conducted between March and June 1995. The census methodology followed Struhsaker (1981) and Whitesides et al. (1988). In accordance with the terms of reference for the surveys, transects approximately $5 \mathrm{~km}$ long were used in the park (Fig. 1). Transect M1, which was previously used for vegetation studies, in the central area of the park's forest block, had an even mix of the two main forest types of Odzala ( $2.86 \mathrm{~km}$ of open-canopy Marantaceae forest and $1.64 \mathrm{~km}$ of closed-canopy primary forest). Transect M2 was set up in the Lékénie riparian forest, where the major forest types are thicket and dense inundated forest (1.94 and $1.81 \mathrm{~km}$, respectively), with some patches of swamp forest $(1.1 \mathrm{~km})$, and followed a prescribed transect direction adjusted to follow an important drainage course (Fig. 1).

Three observers (M. Bermejo, G. Illera and the guide R. Ngounga) conducted 39 single-observer transect samples, 14 along transect M1 and 25 samples along transect M2. Surveys started between 06.00 and 06.50 hours, only when light and weather conditions were favourable for observation, and ended between 12.00 and 13.00 hours. Transects were walked at a rate of between 0.9 and $1.5 \mathrm{~km} / \mathrm{h}$ depending on trail conditions and brief stops were made regularly to listen and increase the probability of detecting cryptic primate groups. Special care was taken to ensure that no group was counted twice. The number of groups of monkeys seen were the accumulated totals recorded over the period of the surveys. The following information was recorded for all monkey groups encountered on each transect: species; group size; date and time detected; observation duration; transect position; habitat type; perpendicular distance from the transect trail to the estimated geometric centre of the group; and vertical position of the group in forest strata. To determine the proportion of each habitat type along the transects, a habitat classification using the categories above was assigned every $50 \mathrm{~m}$ along each trail.

The size $(n)$ of the sample is an important consideration in survey design. To fulfil statistical requirements, $n$ should usually be 60-80 encounters for a given target species, although a sample size of 40 may be adequate for some purposes (Buckland et al., 1993).

Along transect M2, where eight monkey species were observed, there was great variation in the number of 
groups observed each time the transect was walked. Therefore, in order to provide a sample size that would be adequate for statistical analysis, transect M2 was censused more often than transect M1.

Data collection should be carried out throughout the year, with transects being walked every month until $n=60-80$ for each species in each habitat. This was planned at Odzala, but was not possible because of logistical problems. However, Maisels (1995) conducted a 5-month observational study, based on the identification of all groups of monkeys in a given area of the Lékénie riparian forest (ONP). Both studies (Maisels, 1995; this study) showed similar indices of abundance for the species concerned.

\section{Gorilla and chimpanzee census}

The methods for a quantitative census of gorilla and chimpanzee populations used in this study followed Tutin \& Fernandez (1984). The census of gorillas and chimpanzees was conducted between April and July 1994 along seven transects that covered three habitat types (closed-canopy primary forest, open-canopy Marantaceae forest and swamp forest (Fig. 1). Because of the short duration of our study, the number of transects established was limited to forested areas, despite the fact that gorillas have been shown to nest occasionally along the savannah/forest edge or in the savannah itself in other study areas (Carroll, 1988; Tutin et al., 1995).

Except for transect A5, which had been used previously for vegetation studies, the route of each transect was decided in advance by plotting the direction and distance on a 1:2000 map (Fig. 1). Seven routes totalling $68.1 \mathrm{~km}$ were drawn on a map, on a compass bearing crossing the drainage in order to include a representative sample of the main vegetation types. In the field, a compass was used to maintain the predetermined course, and the distance covered was measured with the aid of a thread measuring device. Transects were walked only once, on the day that the census was carried out, to eliminate bias resulting from disturbance of gorillas. Three or four local people were employed to search for nests from the transect line. Walking speed, when looking for nests in areas dominated by a complex tangle of Marantaceae overhead, averaged $0.3 \mathrm{~km}$ / h. Along transect lines all signs of gorillas and chimpanzees were recorded, including: feeding sites; tracks; trails; dung; and nests. At each nest site observed from the transect line, we recorded data following Tutin \& Fernandez (1984): species; location and distance along the transect line; perpendicular distance of the nest from the transect line; habitat type; age class; height; plant species used in construction; construction type for each nest; and nest group size. We recorded gorilla and chimpanzee sign encounters, in addition to broad habitat classes. When a qualitative change in vegetation type occurred, the vegetation type and distance along the transect were recorded.

Gorilla nests were distinguished from chimpanzee nests by: construction type; height distribution of nests within the nest group (gorilla nest groups often have one or more nests on the ground and are rarely found above $15 \mathrm{~m}$ ); and gorilla scent, dung or hair in tree nests. Therefore, nest sites were considered to be those of gorilla when, (i) at least one ground nest was present, or (ii) an obvious gorilla sign, e.g. dung of the same age as the nest site, was on the ground below the site. A nest group was defined as a collection of nests of the same age not more than $25 \mathrm{~m}$ apart.

Structural differences in the habitat affected the visibility of nests and so reliable visibility limits were calculated by recording the shortest distance between the transect line and each nest, i.e. the perpendicular distance. This allowed post-hoc determination of the limits of reliable visibility for the nests of each species in each habitat type and hence calculation of the area sampled by the transect.

Gorilla and chimpanzee densities were calculated and compared with results from other sites in Central Africa. We used the following formula to calculate the population density of weaned (nest-building) individuals (Tutin \& Fernandez, 1984): (number of nest groups within reliable visibility limits/area sampled $) \times(1 / x$, where $x=$ number of days a nest remains visible) $\times$ (median nest group size). The strip width sampled for gorilla nest groups was $20 \mathrm{~m}$ (because visibility is limited beyond $10 \mathrm{~m}$ on either side of the transect), while the strip width for chimpanzees was $40 \mathrm{~m}$ in closedcanopy primary forest and swamp forest, and $50 \mathrm{~m}$ in open-canopy Marantaceae forest.

The short duration of this study meant that it was not possible to estimate the length of time that chimpanzee and gorilla nests remained visible. Therefore, data from other studies were used to complete the density calculations. Tutin \& Fernandez (1984) found that chimpanzee nests in Gabon were visible for 113.6 days and we used this figure in our calculations. Data on duration of gorilla nests are more problematic. Tutin \& Fernandez (1984) monitored 223 gorilla nests at Belinga, north-east Gabon, and found a mean nest duration of 53.6 days. However, mean duration of gorilla nests at the Lopé reserve in Gabon was 78 days (Tutin et al., 1995), 32 per cent longer than in the previous study. The species and methods used for nest construction were different in the two studies, with most nests at Belinga being in Musanga cecropioides, a fast growing softwood species, and where nest decay 
Table 1 Relative abundance of guenon, mangabey and colobus groups observed on transects M1 and M2 in Odzala National Park, Congo, between March and June 1995

\begin{tabular}{|c|c|c|c|c|}
\hline \multirow[b]{2}{*}{ Species } & \multicolumn{2}{|l|}{ M1 } & \multicolumn{2}{|l|}{ M2 } \\
\hline & No. of groups & Relative abundance (per cent) & No. of groups & Relative abundance (per cent) \\
\hline \multicolumn{5}{|l|}{ Guenons } \\
\hline Cercopithecus nictitans & 65 & 49.6 & 24 & 21.8 \\
\hline Cercopithecus cephus & 37 & 28.3 & 21 & 19.1 \\
\hline Cercopithecus pogonias & 10 & 7.6 & 12 & 10.9 \\
\hline Cercopithecus neglectus & - & - & 16 & 14.5 \\
\hline Miopithecus talapoin & - & - & 10 & 9.1 \\
\hline \multicolumn{5}{|l|}{ Mangabeys } \\
\hline Cercocebus albigena & 19 & 14.5 & 9 & 8.2 \\
\hline Cercocebus galeritus & - & - & 7 & 6.4 \\
\hline \multicolumn{5}{|l|}{ Colobus } \\
\hline Colobus guereza & - & - & 11 & 10 \\
\hline Total & 131 & 100 & 110 & 100 \\
\hline
\end{tabular}

was rapid because branches were broken rather than bent during nest construction. Most nests at Odzala were in Camptostylus mannii, also a softwood species, and we used the nest degradation rates of 53.6 days determined at Belinga in our calculation of gorilla densities.

The census method used in these studies has been reappraised recently for two major reasons: first, up to 26 per cent of gorilla nest-sites can be mistakenly recorded as chimpanzee nest-sites when only tree nests remain visible (Tutin et al., 1995); second, some individuals do not build a nest while others make more than one (Remis, 1993). As a result, surveys using these methods give only a partial insight into population structure (Fay, 1997). However, using data based on the nest counts as well as accessory data sets (observation of animals), it is possible to document population trends with greater precision.

\section{Results}

\section{Monkey census}

During our survey we found eight species of monkey: greater white-nosed monkey Cercopithecus nictitans, moustached monkey Cercopithecus cephus, crowned guenon Cercopithecus pogonias, De Brazza's monkey Cercopithecus neglectus, talapoin Miopithecus talapoin, white-cheeked mangabey Cercocebus albigena, agile mangabey Cercocebus galeritus and guereza Colobus guereza. Carpaneto (1993) collected a skin of a black colobus Colobus satanas from a hunter a few kilometres outside the western border of the park. This is the first record of this species in the Odzala area and represents the eastern limit of their known distribution.
This species, however, was not sighted during this survey.

\section{Species richness}

Monkey species richness was highest in the riparian forest, with all eight species occurring in dense inundated forest and thicket and six of the eight species (C. nictitans, C. cephus, C. pogonias, Cercocebus albigena, Cercocebus galeritus and Colobus guereza) occurring in swamp forest, whereas only four species (C. nictitans, C. cephus, C. pogonias and Cercocebus albigena, were found in the terra firma forest (consisting of opencanopy Marantaceae and closed-canopy primary forest).

\section{Species abundance}

Table 1 shows the total number of groups and the relative abundance of species found on the two transects. The most commonly sighted species on both transects were $C$. nictitans (49.6 and 21.8 per cent of sightings, respectively) and C. cephus (28.2 and 19.1 per cent, respectively).

Table 2 indicates species abundance (groups per $\mathrm{km}$ ) in the different habitat types: $C$. nictitans was the most commonly seen species in four different habitats: closed primary forest, Marantaceae forest, dense inundated forest and swamp forest (1.4, 0.82, 0.28 and 0.20 groups per $\mathrm{km}$, respectively). However, the most commonly sighted species in thicket forest was $C$. neglectus $(0.24$ groups per $\mathrm{km})$ followed by $C$. cephus (0.20 groups per $\mathrm{km}$ ).

Three species of the four $-C$. nictitans, C. cephus and Cercocebus albigena-present in terra firma forest were most abundant in closed-canopy primary forest (1.4, 1.0 and 0.6 groups per $\mathrm{km}$, respectively) while the 
fourth, C. pogonias, was most abundant in open-canopy Marantaceae forest ( 0.2 groups per $\mathrm{km})$. Six of the eight species present in riparian forest (C. nictitans, C. pogonias, M. talapoin, Cercocebus albigena, Cercocebus galeritus and Colobus guereza) were most abundant in dense inundated forest $(0.09-0.28$ groups per $\mathrm{km}$ ), while C. neglectus was most abundant in thicket forest $(0.24$ groups per $\mathrm{km})$ and C. cephus was equally abundant in both habitats ( 0.20 groups per $\mathrm{km})$. Odzala appears to have one of the highest abundances of guenons of the terra firma forests in Central Africa.

\section{Gorilla and chimpanzee census}

Species abundance and density

A total of $68.1 \mathrm{~km}$ was censused along seven transects, $33 \mathrm{~km}$ in closed-canopy primary forest, $30.5 \mathrm{~km}$ in opencanopy Marantaceae forest, and $4.5 \mathrm{~km}$ in swamp forest. We found 630 gorilla nests, of which 427 (67.7 per cent) were visible from the transect line. Gorilla nests were most abundant in open canopy Marantaceae forest (12.1 nests $/ \mathrm{km}$; Table 3 ) and 81.6 per cent of the nests had been made on the ground using herbaceous material, in particular Haumania liebrechtsiana. The remaining nests were in trees 1-14 $\mathrm{m}$ above ground level, with a mean nest height of $5.5 \mathrm{~m}$.

The 427 gorilla nests were found in 65 groups, with a mean size of 6.6 nests per group (range 1-26), and a median size of seven nests in open-canopy Marantaceae forest and 3.5 nests in closed-canopy primary forest. Gorilla densities were high in Marantaceae forest (Table 3). The maximum density estimate of 11.3 nesting gorillas/sq $\mathrm{km}$ in Marantaceae forest in this study is the highest recorded for any vegetation type surveyed, and is comparable with estimates from the Central African Republic (10.96 gorillas per sq km; Carroll, 1988) in sec- ondary forest. The mean density estimate of 5.4 nesting gorillas per sq $\mathrm{km}$ in Odzala is the highest recorded anywhere. The most commonly observed gorilla feeding remains were Haumania liebrechtsiana, Megraphrynium sp., Palisota sp. and Aframomum sp.

We found 966 chimpanzee nests, 860 (89 per cent) of which were visible from the transect line. All chimpanzee nests were between 2 and $35 \mathrm{~m}$ above the ground with the majority ( 66.3 per cent) between 5 and $10 \mathrm{~m}$ (mean, $14 \mathrm{~m}$ ). Chimpanzee nests were most abundant in closed-canopy primary forest (14 nests per $\mathrm{km}$; Table 3 ) followed by open-canopy Marantaceae forest (12 nests per $\mathrm{km}$ ).

The 860 chimpanzee nests were found in 378 groups with a mean of 2.3 (range 1-14), and a median size of 2 . The park contains one of the highest densities of chimpanzees recorded, with a maximum of three individuals per sq $\mathrm{km}$, which is comparable with estimates from Kalinzu forest, Uganda (2.8-4.7 individuals per sq km; Hashimoto, 1995), where the forest is also characterized by a mosaic structure.

\section{Factors affecting gorilla nest construction}

Nest counts are powerful tools for population censuses and demographic studies of great apes, but problems exist in interpreting data on lowland gorilla nests. Habitat type, group size and season all affect nest construction type. Baseline data on nests, in addition to documenting aspects of gorilla behaviour and ecology, have important implications for census work in tropical forest habitats. In order to assess the effect of these factors, we compared data on gorilla nests from nest- sites recorded during a 24-month study on the ecology of lowland gorillas at the Lossi forest study site $(50 \mathrm{~km}$ to the east of Odzala National Park), where nine gorilla groups have been intermittently followed in a $25-\mathrm{sq} \mathrm{km}$ study area:

Table 2 Abundance (groups $/ \mathrm{km}$ ) of mangabeys, guenons and colobus by habitat type on transects M1 and M2 in Odzala National Park, Congo, between March and June 1995

\begin{tabular}{|c|c|c|c|c|c|c|c|c|c|c|c|c|c|c|c|c|c|}
\hline \multirow[b]{2}{*}{ Habitat } & \multirow[b]{2}{*}{ Distance $(\mathrm{km})$} & \multicolumn{8}{|c|}{ No. groups } & \multicolumn{8}{|c|}{ Groups per km } \\
\hline & & $\mathrm{Cn}$ & $\mathrm{Cc}$ & $C p$ & $\mathrm{Ce}$ & Mt & $\mathrm{Ca}$ & $\mathrm{Cg}$ & $\mathrm{Co}$ & $\mathrm{Cn}$ & $\mathrm{Cc}$ & $\mathrm{Cp}$ & $\mathrm{Ce}$ & Mt & $\mathrm{Ca}$ & $\mathrm{Cg}$ & $\mathrm{Co}$ \\
\hline \multicolumn{18}{|c|}{ MI (terra firma forest transect) } \\
\hline Marantaneceae forest & 40.0 & 33 & 14 & 9 & & & 4 & & & 0.82 & 0.30 & 0.20 & & & 0.10 & & \\
\hline Closed primary forest & 23.0 & 32 & 33 & 1 & & & 15 & & & 1.40 & 1.00 & 0.04 & & & 0.60 & & \\
\hline Total & 63.0 & 65 & 37 & 10 & & & 19 & & & & & & & & & & \\
\hline \multicolumn{18}{|l|}{ M2 (Riparian forest transect) } \\
\hline Thicket & 48.7 & 6 & 10 & 4 & 12 & 3 & 2 & 1 & 1 & 0.10 & 0.20 & 0.08 & 0.24 & 0.06 & 0.04 & 0.02 & 0.02 \\
\hline Dense inundated forest & 45.6 & 13 & 10 & 7 & 4 & 7 & 5 & 4 & 10 & 0.28 & 0.20 & 0.10 & 0.10 & 0.15 & 0.10 & 0.09 & 0.22 \\
\hline Swamp forest & 27.5 & 5 & 1 & 1 & & & 2 & 2 & 1 & 0.20 & 0.04 & 0.04 & & & 0.07 & 0.07 & 0.04 \\
\hline Total & 121.8 & 24 & 21 & 12 & 16 & 10 & 9 & 7 & 12 & & & & & & & & \\
\hline
\end{tabular}

$\mathrm{Cn}$, Cercopithecus nicitans; Cc, C. cephus; Cp, C. pogonias; Ce, C. neglectus; $\mathrm{Mt}$, Miopithecus talapoin; Ca, Cercoebus albigena; $\mathrm{Cg}$, Cerocebus galeritus; Co, Colobus guereza. 
Table 3 Nest abundance index and densities of gorillas Gorilla g. gorilla and chimpanzees Pan t. troglodytes by habitat type along transects surveyed in Odzala National Park, Congo, between April and July 1994

\begin{tabular}{|c|c|c|c|c|c|}
\hline \multirow[b]{2}{*}{ Habitat type } & \multirow[b]{2}{*}{ Distance $(\mathrm{km})$} & \multicolumn{2}{|c|}{ Nests $/ \mathrm{km}$} & \multicolumn{2}{|c|}{ Individuals/sq km } \\
\hline & & Go & $\mathrm{Ch}$ & Go & $\mathrm{Ch}$ \\
\hline Closed-canopy primary forest & 33.05 & 1.2 & 14.0 & 1.1 & 3.0 \\
\hline Open-canopy Marantaceae forest & 30.52 & 12.1 & 12.0 & 11.3 & 2.1 \\
\hline Swamp forest & 4.53 & 3.9 & 7.1 & 3.7 & 1.5 \\
\hline $\begin{array}{l}\text { Mean abundance and density } \\
\text { Total }\end{array}$ & 68.10 & 5.7 & 11.0 & 5.4 & 2.2 \\
\hline
\end{tabular}

Go, gorilla; Ch, chimpanzee. group sizes $32,20,20,18,17,12,10,7$, and 4 solitaries (M. Bermejo, unpublished data), and data from Lopé reserve, Gabon, with results from our nest-count census. In ONP 18.4 per cent of gorilla nests were in trees at heights of 1-14 m compared with 11.7 per cent of those built by gorilla groups in Lossi and 35 per cent of gorillas nesting in Lopé at heights of $1-35 \mathrm{~m}$. The location of gorilla nests (on the ground or in trees) varied between different study sites. At Lopé 8.3 per cent of the nest-sites had only tree nests and a further 10.2 per cent consisted of tree nests with a single ground nest. However, at Lossi (204 fresh gorilla nestsites, $n=3432$ nests from six different groups) we found no gorilla nest-sites consisting of only tree nests or of mainly trees with only a single ground nest.

At Lopé, most tree nests were built in wet months and in habitats where herbaceous plants were scarce, suggesting that gorillas chose to nest in trees rather than travel long distances to find herbaceous plants for ground nests. Odzala is characterized by a rich variety of habitats, including forests dominated by the densest formations of Marantaceae known to date. At Odzala and Lossi, gorillas often stay close to a concentration of particularly limited resources such as fruiting trees and they do not need to travel to find an ideal ground nesting site.

Variability in nest construction by different populations may be the result of variation in vegetation types and densities at different sites, producing differences in terms of available nesting materials in the habitats that gorillas exploit. Furthermore, the sampling problems presented by gorilla nests may make accurate census difficult, but if standard methods are employed at the same time of year, nest counts along transect lines can doocument population trends with greater precision because deviations from the assumptions of line transects will be similar (Tutin et al., 1995).

Census data are essential for the conservation and management of protected areas. It is important to estimate numbers but probably more important to monitor trends to establish whether populations are stable, declining or increasing over time, and to document responses to habitat alteration.

\section{Discussion}

Odzala National Park has the richest primate fauna of Central Africa, with 10 taxa of diurnal primates confirmed in the park. Furthermore, the forests in Odzala, and those to the east and north, probably hold the largest population of gorillas in Africa today. Magliocca et al. (in press) studied western lowland gorillas visiting a clearing of $c .18$ ha in the north of ONP where 420 gorillas (36 groups and 18 solitaries) were identified. This suggests that gorilla densities are very high in this region with the author concluding that gorilla densities are probably close to 11 individuals per sq $\mathrm{km}$.

It has been suggested that variations in primate densities between sites may result from the presence or absence of competitive species (Harrison \& Hladik, 1986), historical events (such as disease; Butynski, 1990), variation in plant species composition, structural heterogeneity of the habitat and patterns of seasonal change in the availability of food (Oates et al., 1990). The abundance of primates at ONP may be a result of the high productivity of the forest, a complex mosaic of vegetation types and low poaching pressure. However, more comparative data are required (on primate diets and biomass, and on plant species composition and fruiting phenology) before conclusions can be reached. Tutin et al. (1997) suggested that the most likely explanation of low primate biomass at Lopé is the occurrence of an ecological 'catastrophe' in the fairly recent past from which populations have not yet recovered.

The results of this study suggest that riverine forests are important for conserving the diversity of monkey species in the region. These forest types are therefore of particular importance when considering management options for the area. At Odzala, the abundance of C. nictitans, C. cephus and C. albigena is particularly high and the abundance of $C$. neglectus and $M$. talapoin is similar to that in north-east Gabon (Gautier-Hion, 1971, for M. talapoin; Gautier-Hion \& Gautier, 1978, for C. neglectus).

Odzala National Park contains the largest area of open-canopy Marantaceae forest known to date (Hecketsweiler et al., 1991). Because of its structure and 
dense undergrowth, Marantaceae forest is often misclassified as secondary vegetation and, as such, tends to be assigned a low conservation priority. However, both Marantaceae forest and clearings are known to be attractive sites for gorillas that range in search of herbaceous plant food (Rogers \& Williamson, 1987; Fay \& Agnagna, 1992; White, 1994; Nishihara, 1995) and frequent the clearings to feed on abundant herbaceous vegetation (Olejniczak, 1996; Fay, 1997; Magliocca et al., in press).

Although large groups of gorillas ( $>26$ individuals) are known from montane forests, this study is the first that observed such large groups in lowland tropical forests. It is difficult to draw conclusions, but it seems likely that maximum group size is not constrained by within-group competition for fruit. Activities of sympatric forest elephants, which create the herbaceous vegetation by opening up the forest, may also have a large influence on habitats and thus the densities of gorillas (Nishihara, 1991). White (1994) estimated densities of mammals in five sites in lowland semi-evergreen tropical rain forest in the Lopé Reserve, central Gabon. Two of the sites were located in Marantaceae forest, where densities of these important foods were high and this probably explained the higher biomass of gorillas and elephants in these areas. However, data from vegetation surveys at Ndakan, in the Central African Republic (Fay, 1997) indicate that Ndakan has more terrestrial herbaceous vegetation available to gorillas than is found at Lopé. If the difference in densities and group size found at the two sites could be attributed to one variable, then the amount of terrestrial herbaceous vegetation would rank highest. The evidence from ONP follows this trend. In the Likouala region in northern Congo calculated gorilla densities are high (5.8 nesting gorillas per sq km) where Raphia is present (Fay et al., 1990).

Despite the high numbers of gorillas and their widespread distribution in Congo, gorilla populations should still be considered to be Vulnerable because of the continuing expansion of logging and associated hunting (Wilkie et al., 1992). It is possible that the Vulnerable criterion rate of decline of 50 per cent within 100 years will be reached, because so many gorillas in the two countries that harbour most of the world's population (Gabon and Congo) live outside conservation areas (Harcourt, 1996). We have been studying the ecology of lowland gorillas and chimpanzees at Lossi (50 km south-west of ONP) since 1994. Lossi forest is an example of gorillas living at unusually high densities outside a conservation area. We are currently developing a pilot western lowland gorilla tourism programme, which will channel benefits back to local communities and thus encourage long-term conserva- tion. The public awareness activities associated with this programme will contribute to the preservation of Odzala's exceptional primate fauna.

\section{Acknowledgements}

This study was carried out as part of the ECOFAC programme, supported by the European Union and developed by AGRECO-CIRAD Forêt. We thank $\mathrm{Mr}$ Tsila, Director of the DFF of the Ministère des Eaux et Forêts for permission to work in Odzala. Thanks particularly go to Germán Illera for help with the data collection. We are grateful to $C$. Aveling for revising the English and drawing the map. Thanks to the following colleagues: Alick Cruickshank, Fiona Maisels and two anonymous reviewers for constructive comments on the manuscript.

\section{References}

Blake, S. (1995) Swamp gorillas in northern Congo. African Journal of Ecology, 33, 285-290.

Buckland, S.T., Anderson, D.R., Burnham, K.P. \& Laake, J.L. (1993) Distance Sampling. Estimating Abundance of Biological Populations. Chapman \& Hall, London.

Butynski, T.M. (1990) Comparative ecology of blue monkeys (Cercopithecus mitis) in high- and low-density subpopulations. Ecological Monographs, 60, 1-26.

Carpaneto, G.M. (1993) Parc National d'Odzala-Ethnologie, Faune et Ecotourisme. Rapport ECOFAC, Bruxelles.

Carroll, R. (1988) Relative density, range extension and conservation potential of the lowland gorilla (Gorilla gorilla gorilla) in the Dzanga-Sangha region of southwestern Central African Republic. Mammalia, 53, 309-323.

Dowsett-Lemaire, F. (1995) Contribution à l'étude de la végétation du Parc National d'Odzala (Congo). Projet Ecofac-Composante Congo AGRECO-CTFT, Bruxelles.

Fay, J.M. (1997) The ecology, social organization, populations, habitat and history of the western lowland gorilla (Gorilla gorilla gorilla). PhD thesis, Washington University.

Fay, J.M. \& Agnagna, M. (1992) Census of gorillas in northern Republic of Congo. American Journal of Primatology, 27, 275-284.

Fay, J., Agnagna, M., Moore, J. \& Oko, R. (1990) Gorillas (Gorilla g. gorilla) in the Likouala swamp forests of North Central Congo: preliminary data on populations and ecology. International Journal of Primatology, 10, 477-486.

Garcia, J.E. \& Mba, J. (1997) Distribution, status and conservation of primates in Monte Alen National Park, Equatorial Guinea. Oryx, 31, 67-76.

Gautier-Hion, A. (1971) L'ecologie du talapoin au Gabon. Revue Ecologie (Terre et Vie), 25, 427-490.

Gautier-Hion, A. \& Gautier, J.P. (1978) Le singe de Brazza: une stratégie originale. Zeitschrift für Tierpsychology, 46, 84-104. 
Harcourt, A.H. (1996) Is the gorilla a threatened species? How should we judge? Biological Conservation, 75, 165-176.

Harrison, M.J.S. \& Hladik, A. (1986) Une primate granivore: le colobe noir dans la forêt du Gabon; potentialité d'évolution du comportement alimentaire. Revue Ecologie (Terre et Vie), 41, 281-298.

Hashimoto, C. (1995) Population census of the chimpanzees in the Kalinzu forest, Uganda: comparison between methods with nest counts. Primates, 36, 477-488.

Hecketsweiler, P., Doumenge, C. \& Mokoko Ikonga, J. (1991) Le Parc National d'Odzala, Congo. IUCN, Programme de Conservation des Forêts. IUCN, Gland, Switzerland and Cambridge, UK.

Kuroda, S. (1990) Ecological interspecies relations between sympatric gorillas and chimpanzees in Ndoki Reserve, Northern Congo. In Abstracts, XIII Congress of the International Primatological Society. Nagoya and Kyoto, Japan.

Lejoly, J. (1996) Biodiversité végétale dans le Parc National d'Odzala (Congo). Rapport ECOFAC-Congo, AGRECO/CTFT, Bruxelles.

Letouzey, R. (1968) Etude Phytogeographique du Cameroun. Encyclopédie Biologique no 69. Editions Paul Lechevalier, Paris.

Magliocca, F., Querouil, S. \& Gautier-Hion, A. (in press) Population structure and group composition of western lowland gorillas in north-western Republic of Congo. American Journal of Primatology.

Maisels, F.G. (1995) Etude sur la structure de la communauté des petits primates diurnes, Parc National d'Odzala, Republique du Congo. Rapport préliminaire. Projet Ecofac-Composante Congo. AGRECO-CTFT, Bruxelles.

Mitani, M. (1990) A note on the present situation of the primate fauna found from south-eastern Cameroon to northern Congo. Primates, 31(4), 625-634.

Mitani, M. (1992) Preliminary results of the studies on western lowland gorillas and other sympatric diurnal primates in the Ndoki Forest in Northern Congo. In Topics in Primatology, vol. 2 (eds N. Itoigawa, Y. Sugiyama, G. Sackett and R. K. R. Thompson), pp. 215-224. University of Tokyo Press, Tokyo.

Nishihara, T. (1990) A preliminary report on the feeding habits of western lowland gorilla (Gorilla gorilla gorilla) in the Ndoki Forest of northern Congo. In Abstracts, XIII Congress of the International Primatological Society. Nagoya and Kyoto, Japan.

Nishihara, T. (1991) Activities in and around swampy areas of western lowland gorillas. Primate Research, 7(2), 158.

Nishihara, T. (1995) Feeding ecology of western lowland gorillas in the Nouabalé-Ndoki National Park, Congo. Primates, 36(2), 151-168.

Oates, J.F., Whitesides, G.H., Davies, A.G., Waterman, P.G., Green, S.M., Dasilva, G.L. \& Mole, S. (1990) Determinants of variation in tropical forest primate biomass: new evidence from West Africa. Ecology, 71, 328-343.

Oko, R. (1990) The present situation of conservation for the wild gorilla in Congo. In Abstracts, XIII Congress of the International Primatological Society. Nagoya and Kyoto, Japan.

Olejniczak, C. (1996) Update on the Mbeli Bai gorillas study, Nouabalé-Ndoki National Park, Northern Congo. Gorilla Conservation News, 10, 5-8.
Regusters, H. (1983) Casual primate observation in the Congo Basin. Antroquest, 25, 3-4.

Remis, M.J. (1993) Nesting behavior of lowland gorillas in the Dzanga-Sangha Reserve, Central African Republic: implications for population estimates and understanding of group dynamics. Tropics, 2(4), 245-255.

Rogers, M.E. \& Williamson, E.A. (1987) Density of herbaceous plants eaten by gorillas in Gabon. Biotropica, 19(3), 278-281.

Rollet, B. (1964) Introduction à I'Tnventaire Forestière du Nord-Congo, vol. II. Annexes et Illustrations. Rapport 1782, FAO, Rome.

Struhsaker, T.T. (1981) Census methods for estimating densities. In Techniques for the Study of Primate Population Ecology (ed. Subcommittee on Conservation of Natural Populations), pp. 36-80. National Academy Press, Washington.

Tutin, C.E.G. \& Fernandez, M. (1984) Nationwide census of gorilla (Gorilla g. gorilla) and chimpanzee (Pan t. troglodytes) populations in Gabon. American Journal of Primatology, 6, 313-336.

Tutin, C.E.G., Parnell, R.J., White, L.J.T. \& Fernandez, M. (1995) Nest building by lowland gorillas in the Lopé Reserve, Gabon: environmental influences and implications for censusing. International Journal of Primatology, 16, 53-76.

Tutin, C.E.G., Ham, R.M., White, L.J.T. \& Harrison, M.J.S (1997) The primate community of the Lopé Reserve, Gabon: diets, responses to fruit scarcity, and effect on biomass. American Journal of Primatology, 42, 1-24.

Vanleeuwe, H., Cajani, S. \& Gautier-Hion, A. (1998) Large mammals at forest clearings in the Odzala National Park, Congo. Revue Ecologie (Terre et Vie), 53, 185-194.

White, R.J.T. (1994) Biomass of rain forest mammals in the Lopé Reserve, Gabon. Journal of Animal Ecology, 63, 499-512.

Whitesides, G.H., Oates, J.F., Green, S.M. \& Kluberdanz, R.P. (1988) Estimating primate densities from transects in an East African rain forest: a comparison of techniques. Journal of Animal Ecology, 57, 345-367.

Wilkie, D.S., Sidle, J.G. \& Boundzaga, G.C. (1992) Mechanized logging, market hunting, and a bank loan in Congo. Conservation Biology, 6, 570-580.

\section{Biographical sketch}

Magdalena Bermejo is currently attached to the Department of Zoology, University of Barcelona. Her main research interests are primate behaviour, ecology, and environmental management of developing countries, particularly in Central Africa. Her current work involves the study of western lowland gorilla behaviour. In this she integrates a pilot gorilla-viewing tourism plan in order to achieve long-term conservation of the species. This study began in 1994 and is ongoing, financed by ECOFAC (European Union). Dr Bermejo has forthcoming articles in the International Journal of Primatology, Primates and Folia Primatologica, and is currently writing a text on ranging and grouping patterns of western lowland gorillas. 